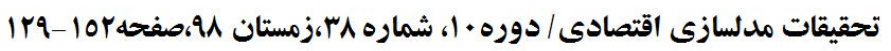

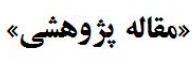

\author{
تأثير رقابت يذيرى ملى بر ضريب نفوذ بيمه \\ در كشورهاى منتخب كارايى محور

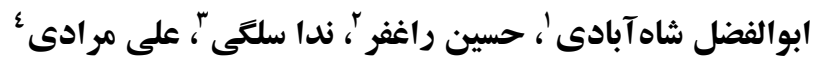

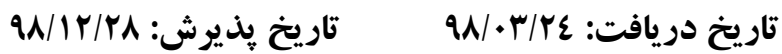

جكيله

بيمه بهعنوان نهاد محورى مقابله با ريسك و همجينين بهعنوان يكىاز نهادهاى

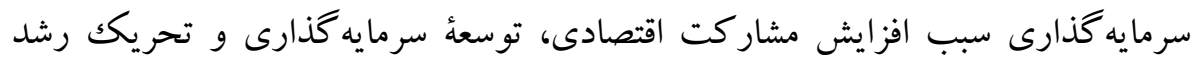

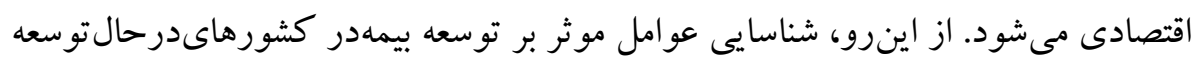

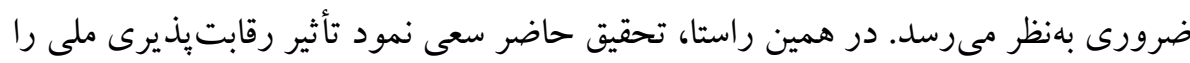

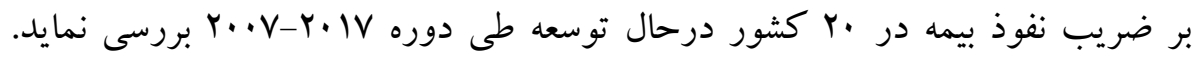

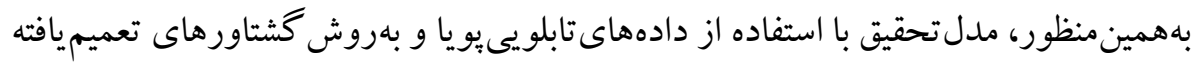

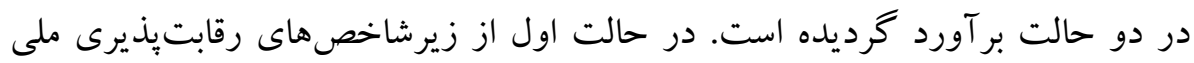
شامل الزامات بنيادين، عوامل فزايندة كارايى و عو امل فزايندة نو آورى و در حالت دوم، از شاخصرقابت يذيرى كل بهعنوان متغير كليدى در مدل تحقيق استفادهدهاست. نتايج نشان داد تأثير شاخصرقابتيذيرى كل و زيرشاخصهاى آن بر ضريب نفوذ بيمه مثبت و معنادار

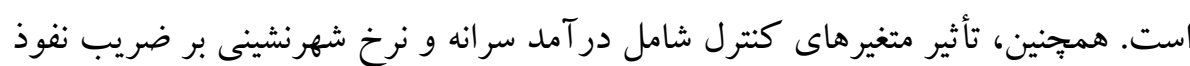
بيمه مثبت و معنادار و تأثير بار تكفل بر ضريب نفوذ بيمه منفى و معنادار است. وازههاى كليدى: ضريب نفوذ بيمه، رقابت يذيرى و دادههاى تابلويى. طبقلبندى G22 :JE، O43، C33.

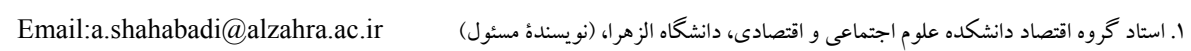
Email:raghfar@alzahra.ac.ir

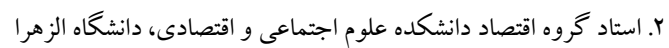
Email:solgineda91@yahoo.com r. ب. كارشناسى ارشد اقتصاد، دانشگاه الزهرا Email:ali.artiman.moradi@gmail.com F
} 


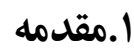

ناطمينانى نسبت به اتفاقات ناكوار و احتمال وقوع حوادث غيرقابل بيشبينى كه جبران خسارت آن خارج از توان افراد حقيقى و حقوقى باشد، منجر به بيدايش واسطه هايى به نام

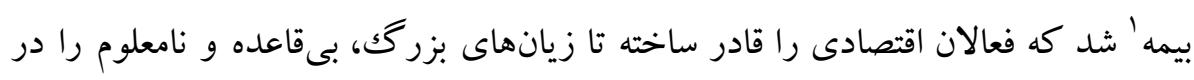

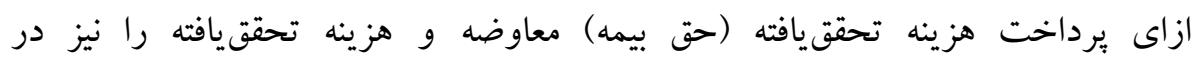

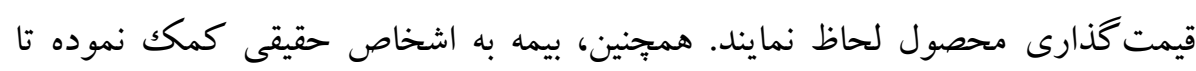

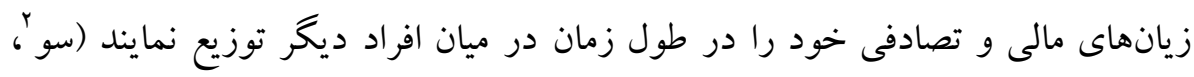

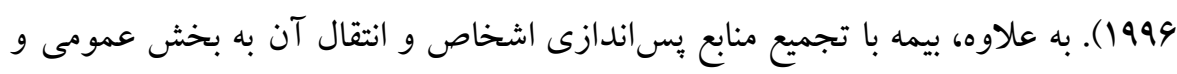

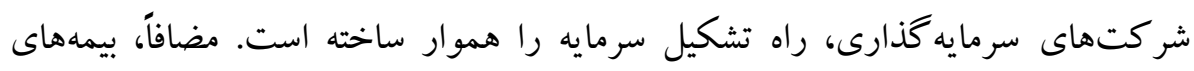

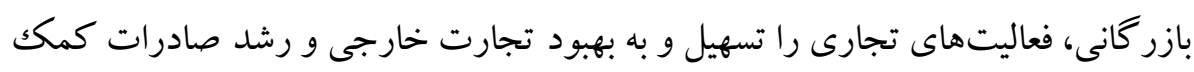

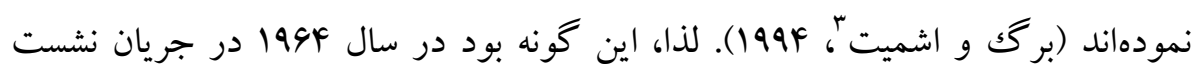

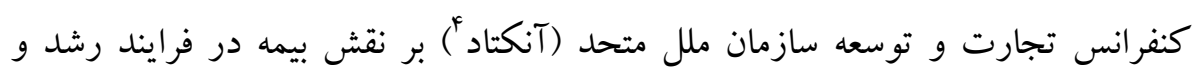

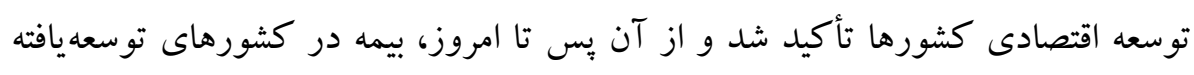

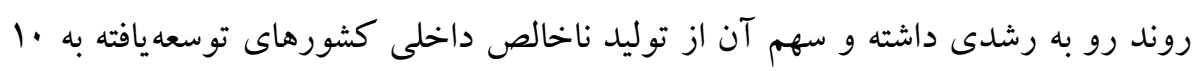
درصد رسيده است. اين در صورتى است كه در كشورهاى درحال توسعه از نقش موثر بيمه در فرايند رشد اقتصادى غفلت شده و سهم بيمه از توليد ناخالص داخلى كشورهاى

$$
\text { درحال توسعه كمتر از r درصد است (سيخماه، } 19 \text { •r). }
$$

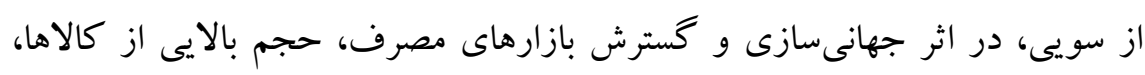

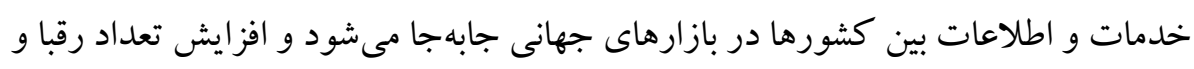

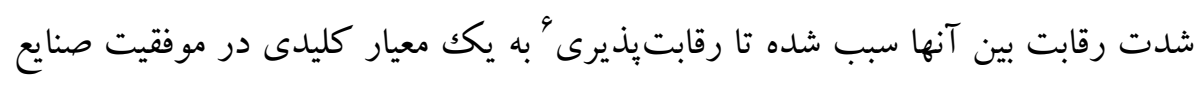

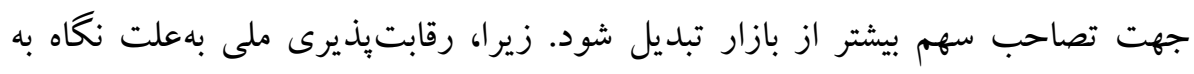

1. Insurance

2. Soo

3. Berg \& Schmidt

4. UNCTAD

5. Sigma

6. Competitiveness 
فرصتهاى جهان بيشِ رو و بسترسازى براى افزايش بهرهورى در صنايع مختلف، زمينه

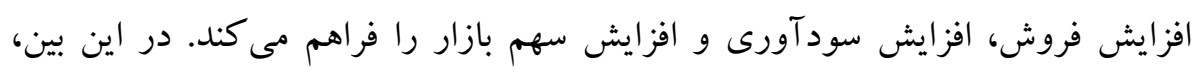

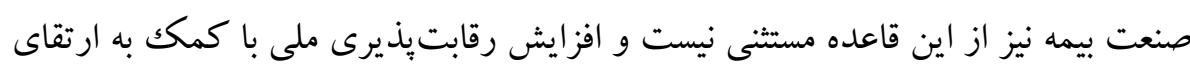
سطح كيفى طرحهاى بيمهاى در دست اجرا و معرفى خدمات بيمهاى جديد منطبق با نيازها

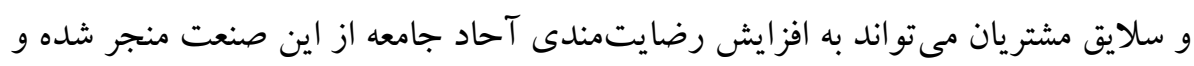
اهداف توسعهاى صنعت بيمه را بيش از ييش محقق سازد. اما، علىرغم اين اهميت نقش رقابتيذيرى در رشد و توسعه صنايع مختلف، بررسى نگارند كان نشان داد تعيين تأثير ار كان رقابتيذيرى ملى بر توسعه صنعت بيمه با استفاده از دادههاى تجربى سابقه ندارد.

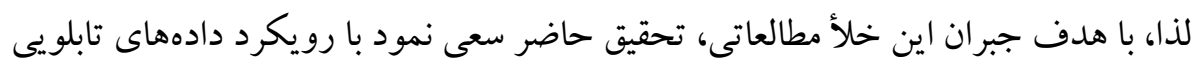

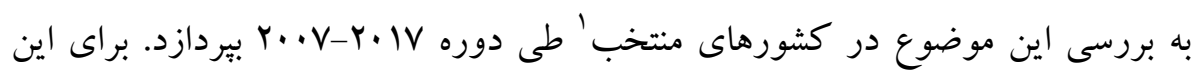

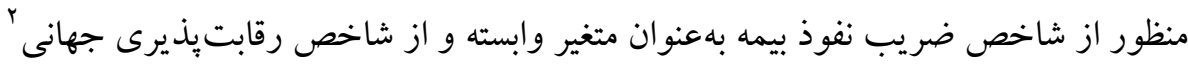
به بنوان متغير توضيحى استفاده شده است.

در ادامه، مفهوم بيمه تعريف شده و اهميت نقش آن در اقتصاد تشريح گرديده است. سبس، مفهوم رقابتيذيرى تعريف، شاخصهاى آن معرفى و سازو كار تأثير آن بر ضريب تهري نفوذ بيمه تببين شده است. بِ از آن، بيشينه مطالعات تجربى تحقيق مرور و جنبه نوابه نو آورى

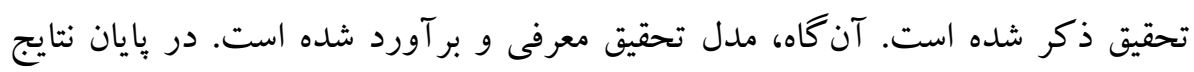
برآوردى، تفسير و بر اساس نتيجه گيرى بعمل آمده جند توصيه سياستى بيشنهاد گرديده

ا. اردن، اكوادور، اندونزى، ايران، برزيل، بلغارستان، يرو، تايلند، تونس، جامائيكا، جين، دومينيكن، روسيه، سريلانكا، صربستان، كلمبيا، مراكث، مصر، مكزيك و وناميبيا. 
كشورهاى داراى سيستم مالى توسعهيافته از رشد اقتصادى بلندمدت و سريعتر بهره

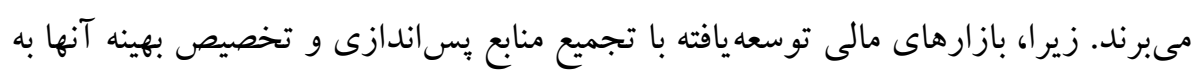

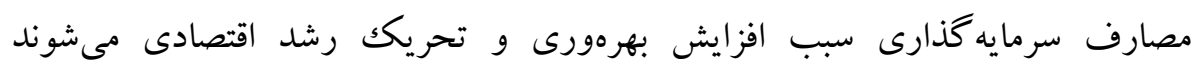

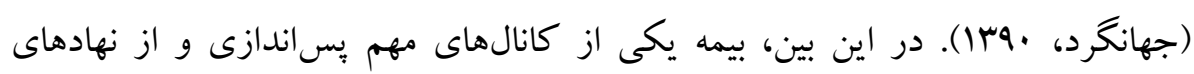

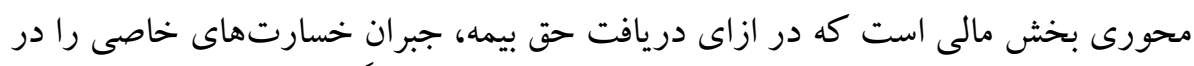

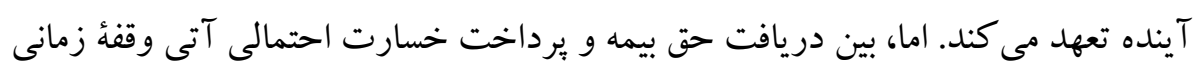
قابل ملاحظهاى وجود دارد كه سبب انباشت وجوه فراوان (ذخاير فنى ') نزد شركت بنهاى

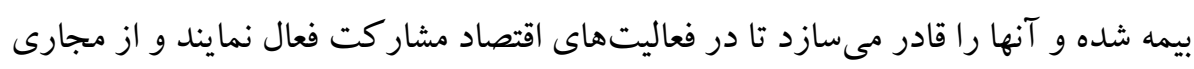
افزايش ثبات مالى، ايفاى نقش جانشينى و مكملى براى برنامههاى تأمين اجتماعى دولت،

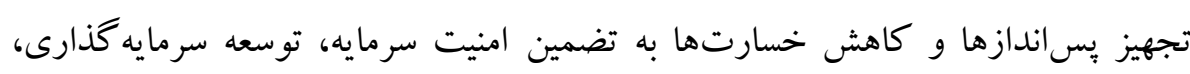

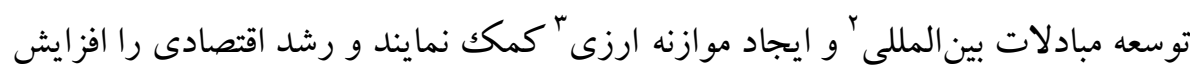

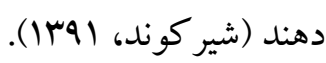

بنابراين، شناسايى عوامل مؤثر بر ضريب نفوذ بيمه كه نماكر رشد صنعت بيمه در قياس با كل اقتصاد است در كشورهاى درحال توسعه ضروريست تا زمينه مناسب برنامهريزى و و سياست گذارى جهت تقويت موارد بسطدهنده و رفع موارد بازدارنده فراهم شود و امكان

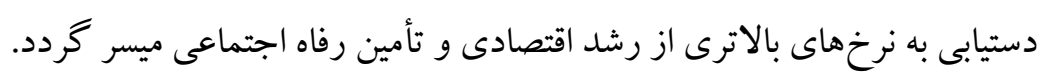

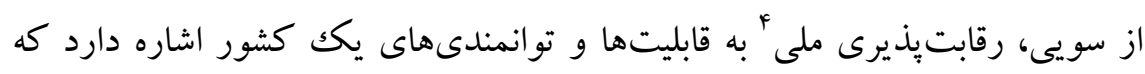

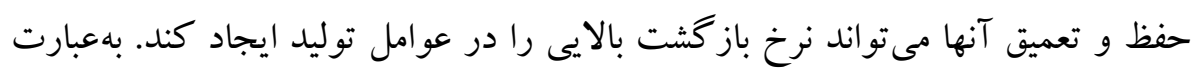

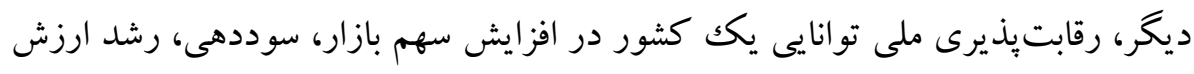

1. Ttechnical Reserves

r. در يكك نظام اقتصادى يويا و توانمند، بيمه بهطور مستقيم و با عقد بيمه اعتبار يا غيرمستقيم و با تقويت اعتبار بيمه كذار نزد

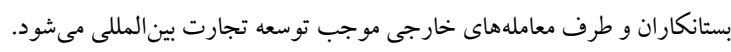

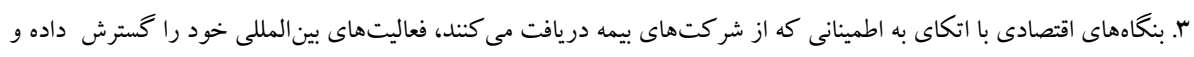

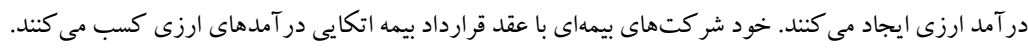
4. National Competitiveness 
افزوده و ماندن در صحنه رقابت عادلانه براى دورهاى طولانى نشان مىدهد (وارث و

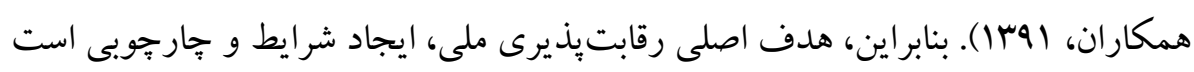

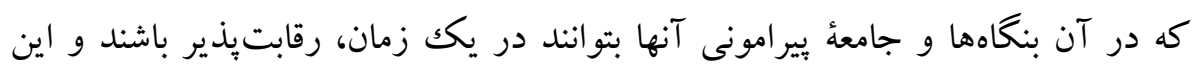

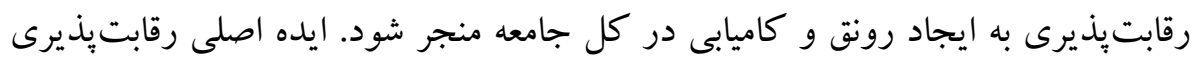

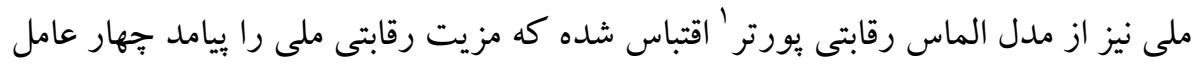

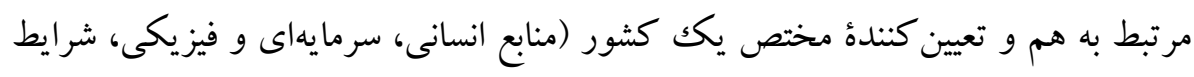

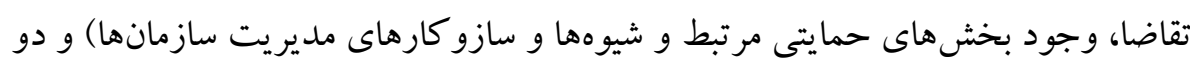

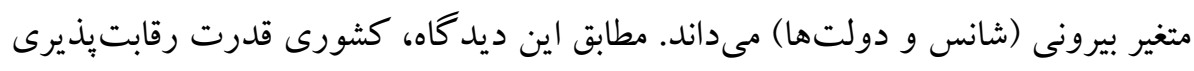

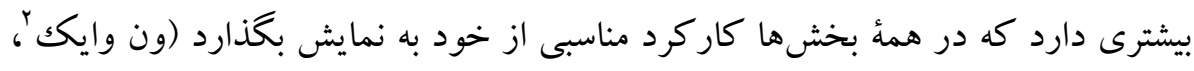

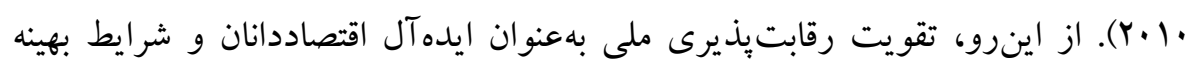

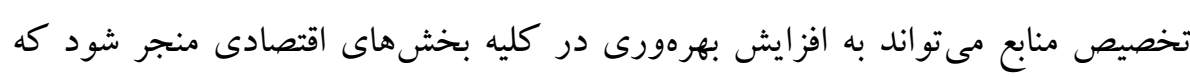

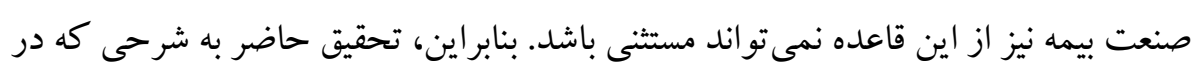

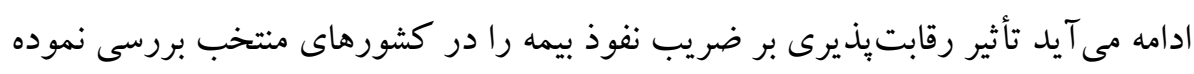

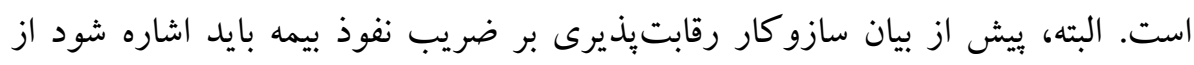

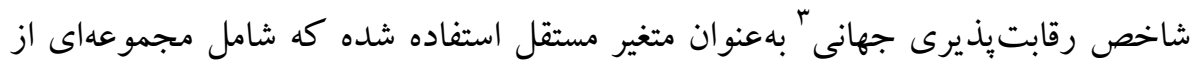
نهادها، سياستها و عوامل ذيل سه شاخص اصلى الزامات بنيادين " (شامل نهادهاء،

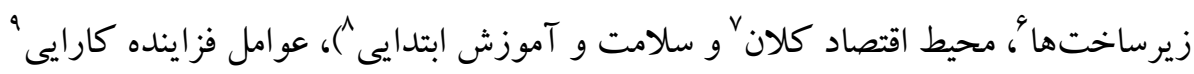

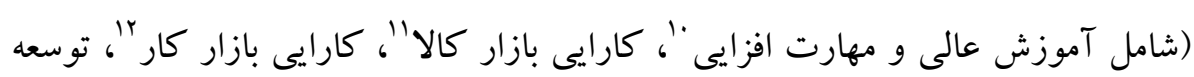

1. Porter's Diamond Model

2. Van Wyk

3. Global Competitiveness Index

4. Basic Requirements

5. Institutions

6. Infrastructure

7. Macroeconomic Environment

8. Health and Primary Education

9. Efficiency Enhancers

10. Higher Education and Training

11. Goods Market Efficiency

12. Labor Market Efficiency 


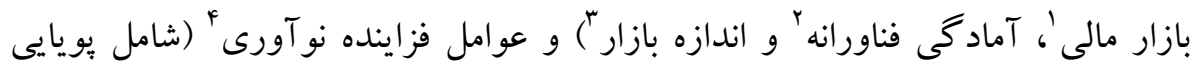

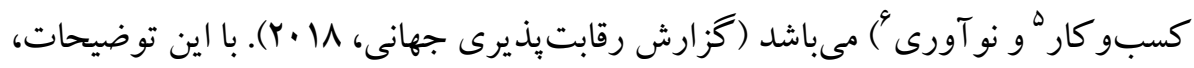

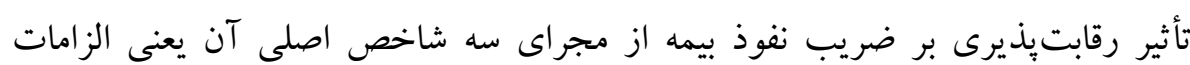

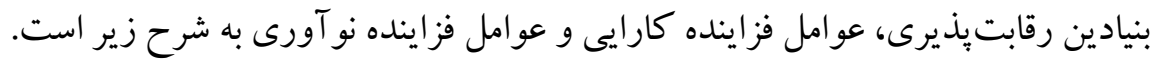
بهبود كيفيت نهادهاى قانونى و سياسى با كاهش انحصارات در صنعت بيمه و افزايش

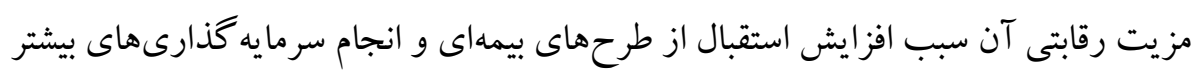

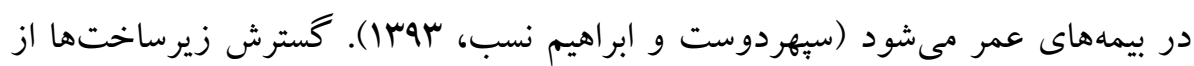
جمله زيرساختهاى فناورى اطلاعات نيز با تسهيل روابط بين مشتريان و شركتهاى بـ بيمه

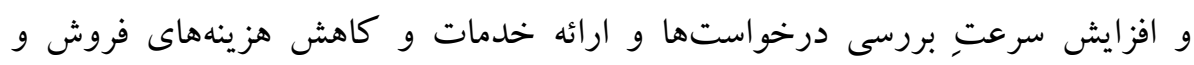
بازاريابى، تسهيل ارتباط درون سازمانى و تسريع انتقال وجوه بين بيمه كذاران و بيمه گركان سبب افزايش خريد خدمات بيمهاى و رشد حق بيمه توليدى مى شود (صادق و همكاران، بوسا). بهبود محيط اقتصاد كلان نيز كه با كاهش نرخ تورم، ثبات نرخ رشد اقتصادى، ثبات نرخ ارز مترادف است به كاهش فضاى ناطمينانى و بيشينىنايذيرى عمومى منجر

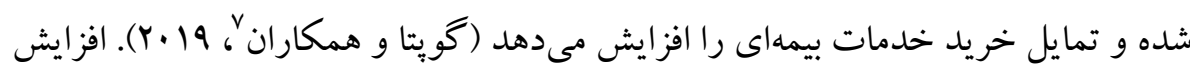
سطح آموزش نيز با رشد دستمزد نيروى كار و تقويت توانخرى مالى افراد به افزايش خريد

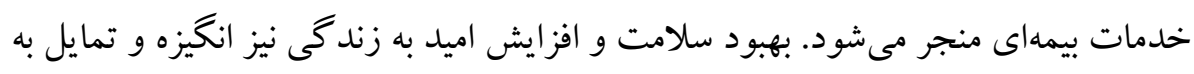

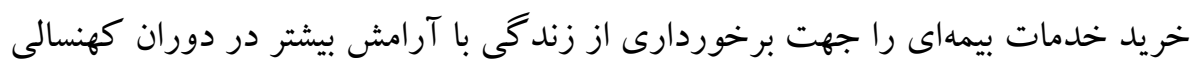

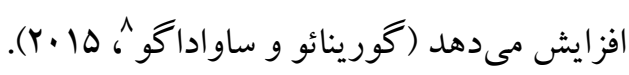

توسعه آموزش عالى با ارتقاى سطح آكاهى عمومى نسبت به مزاياى بيمه و نهادينه

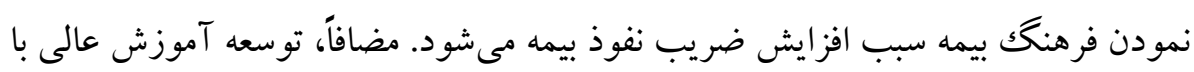

1. Financial Market Development

2. Technological Readiness.

3. Market Size

4. Innovation and Sophistication Factors

5. Business Sophistication

6. Innovation

7. Gupta et al

8. Guerineau \& Sawadogo 
يرورش نيروى انسانى متخصص جهت اشتغال در صنعت بيمه، احتمال نو آورى و طراحى

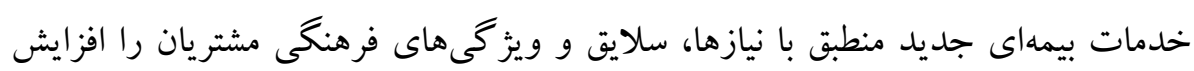

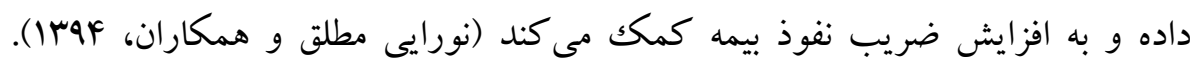

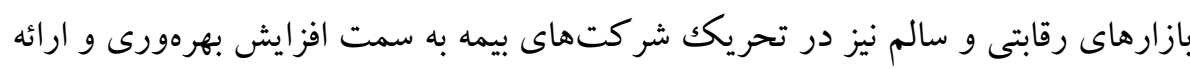

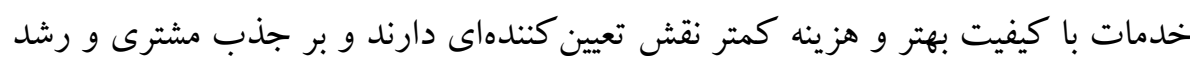

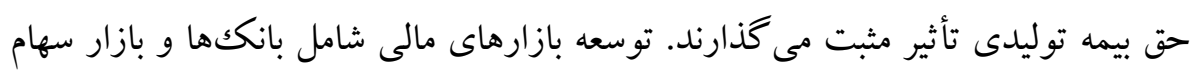
نيز به شركتهاى بيمه جهت استفاده حداكثرى از منابع مالى در اختيار كمكك نموده و

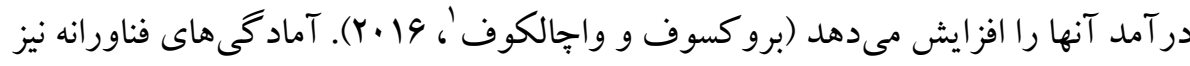
انعطافيذيرى صنعت بيمه در برابر تحولات محيطى را بالا برده و موجب افزايش سرعت

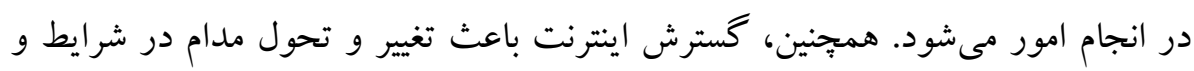

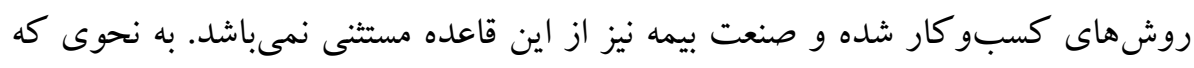

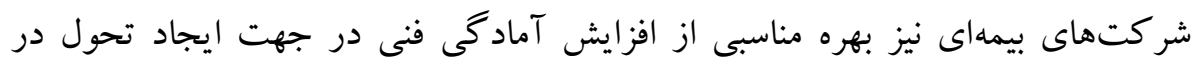

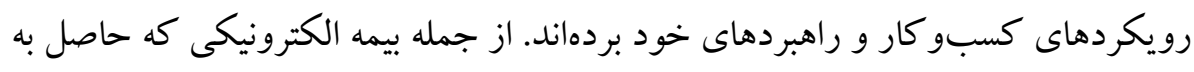
كار گيرى و مديريت فناورى اطلاعات است و باعث ايجاد تحول عميق در نحوه فروش

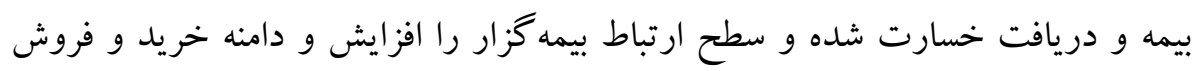

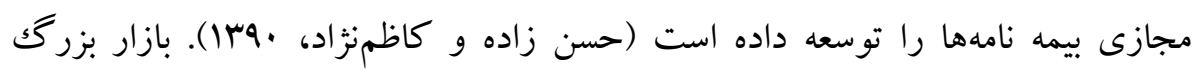

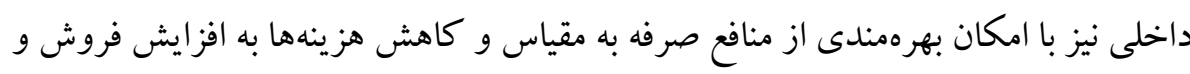

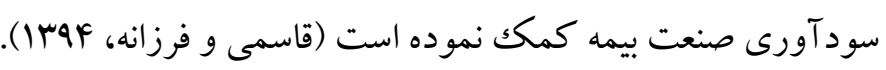

بهبود سيستم ابداع و نوآورى نيز با افزايش كار آيى و كيفيت بازار بيمه و بهبود ابعاد

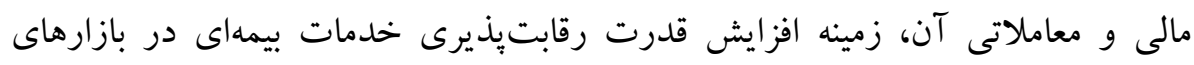

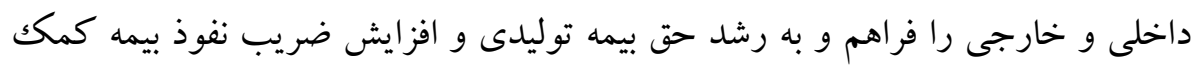

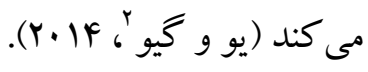

1. Brokesova \& Vachalkova

2. Yu \& Guo 
r. بـ بيشينه تحقيق

بلكينه و همكاران' (Y.19) روابط بيمه و رشد اقتصادى در كشورهاى عضو اتحاديه

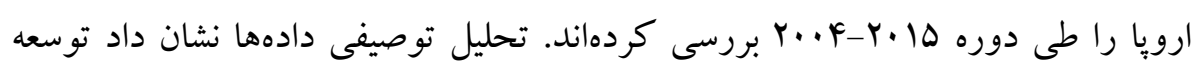
بخش بيمه در كشورهاى ثروتمند اقتصادى مانند انخليس، دانمارك،، فنلاند، ايرلند، فرانسه

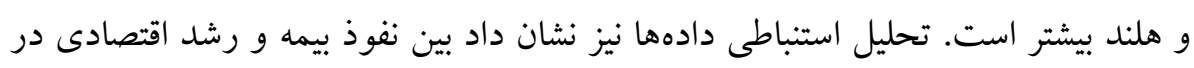
لو كزامبور گك، دانماركى، هلند و فنلاند از نظر آمارى رابطه مثبت و معنادارى وجود داردئ دارد. اما، در اتريش، بلزيك،، مالت، استونى و اسلواكى اين رابطه منفى و معنادار است. ضمناً،

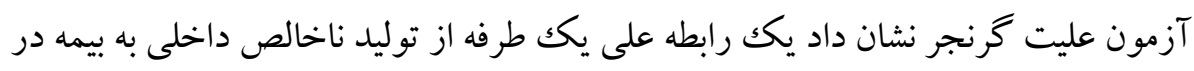

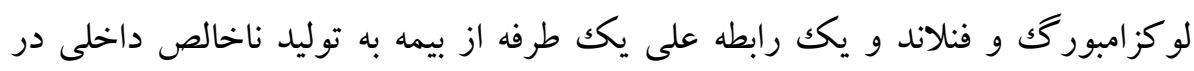
هلند، مالت و استونى وجود دارد. در اتريش اين رابطه على دوطرفه است. در اسلواكى نيز بين توليد ناخالص داخلى و ضريب نفوذ بيمه رابطه على وجود ندارد.

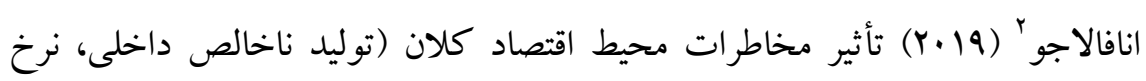

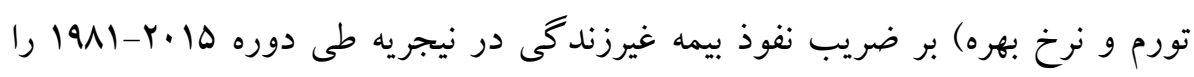

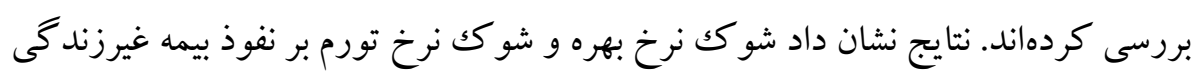

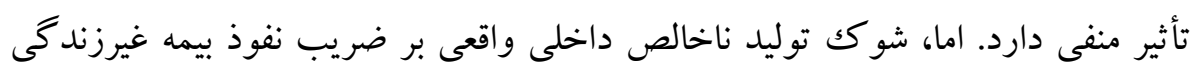
تأثير ندارد.

كويتا و همكاران (Y.19) رابطه خروجى واقعى اقتصاد و نااطمينانى سياستهاى

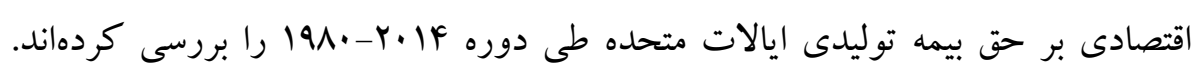

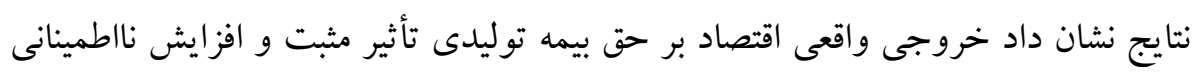

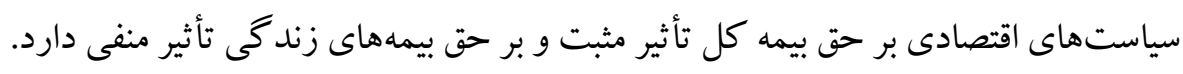




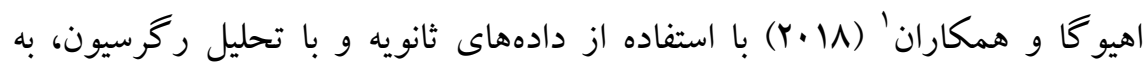
بررسى تأثير نرخ تورم به عنوان يكك متغير اقتصاد كلان بر ضريب نفوذ بيمه در نيجريه

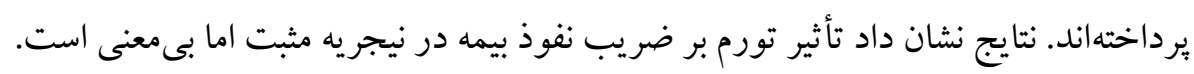

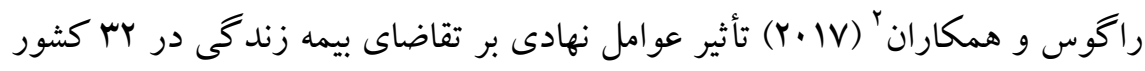

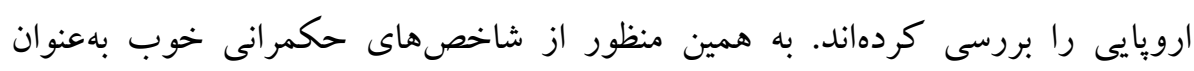
جايكزين عوامل نهادى استفاده شد. نتايج نشان داد تقاضاى بيمه زندگى در در اقتصادهاى

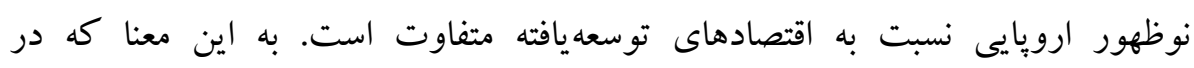

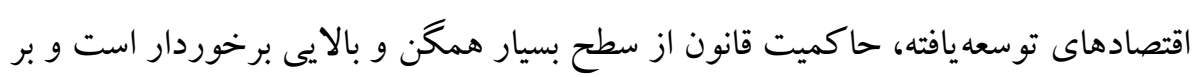

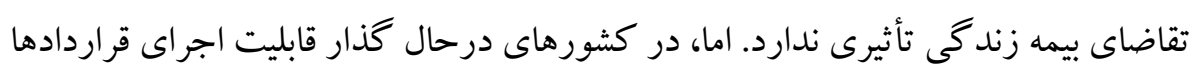

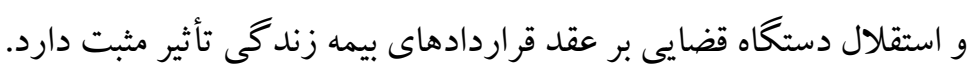

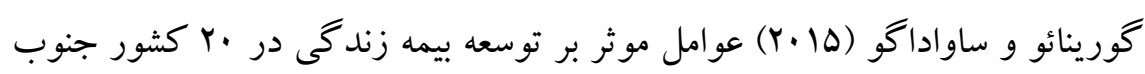

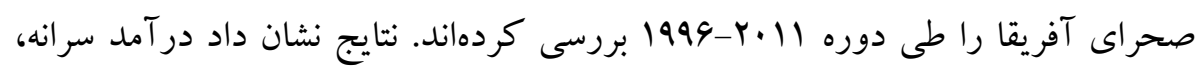
نسبت جمعيت مسن به كل جمعيت، امنيت حقوق مالكيت و ثبات سياسى بر توسعه بيمه

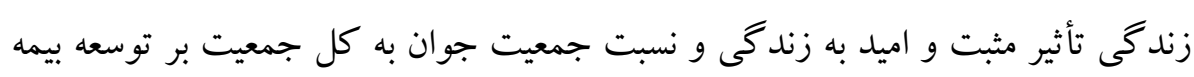
زندگ زأثى تأثير منفى دارند.

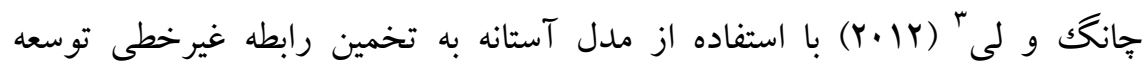
اقتصادى و بيمه زندگى در كشورهاى با درآمد يائين برداختهاند. نتايج نشان داد محيط سياسى و حقوقى بر بيمه زندكى در كشورهاى ياد شده تأثير دارد.

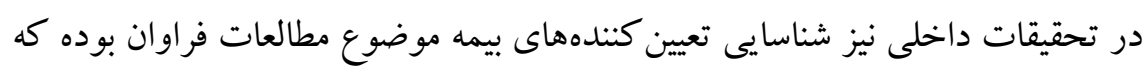

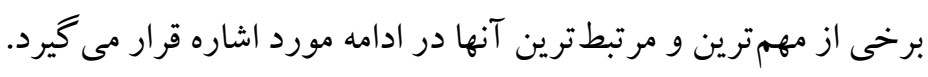

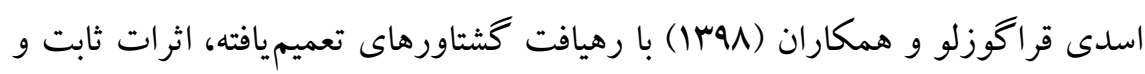
تصادفى به بررسى تأثير جهانى شدن اقتصادى، سياسى و اجتماعى بر ضريب نفوذ بيمه 
زندگى و غيرزندگى در دو گروه از كشورهاى توسعه يافته و كشورهاى جشمانداز ايران در

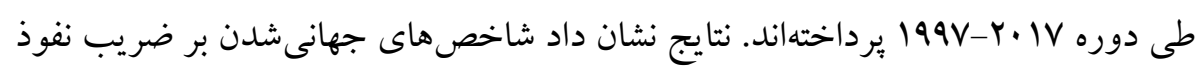

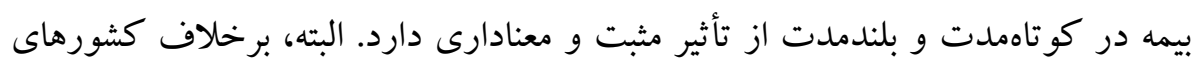
توسعهيافته كه كليه جوانب جهانىشدن (به خصوص جهانى شدن اجتماعى) بر ضريب نفوذ

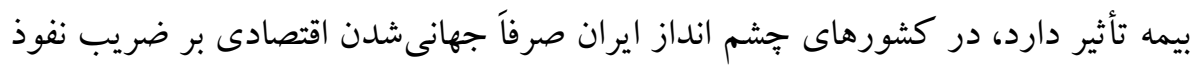

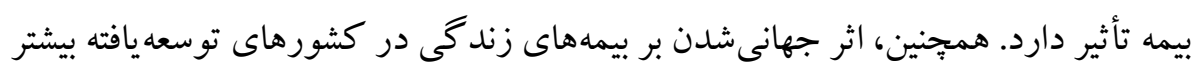
از كشورهاى جشم انداز ايران است.

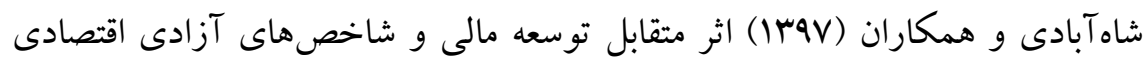
(شاخص كل، اندازه دولت، ساختار قانونى امنيت و حقوق مالكيت، دسترسى به يول سالم، آزادى تجارت خارجى و مقررات) را بر ضريب نفوذ بيمه در پانزده كشور ناموفق در

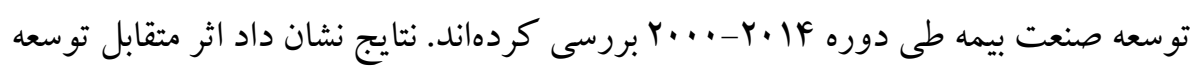
مالى و كليه شاخصهاى آزادى اقتصادى بر ضريب نفوذ بيمه مثبت و معنادار است.

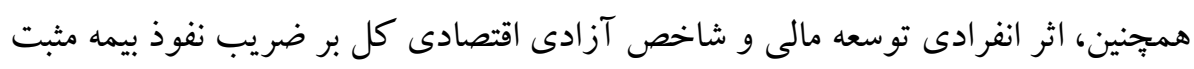

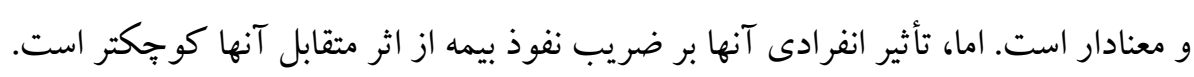

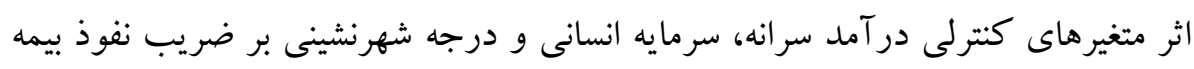
مثبت و معنادار و اثر نرخ بيكارى و تورم بر ضريب نفوذ بيمه منفى و معنادار است.

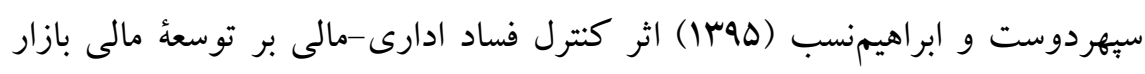

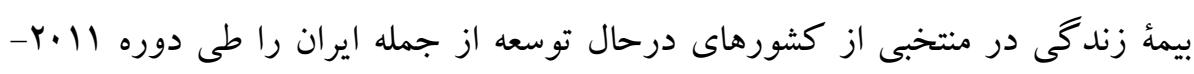

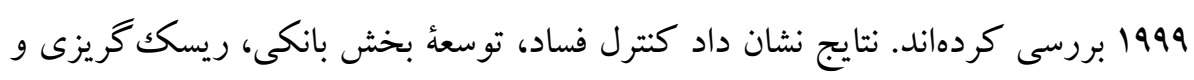

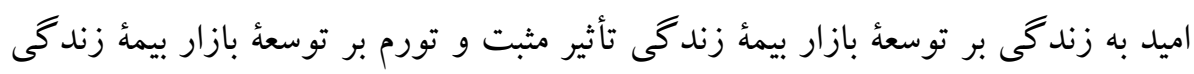
تأثير منفى داشته است. قاسمى و فرزانه (YYYY) تأثير متغيرهاى نهادى و كلان اقتصادى را بر ساختار صنعت

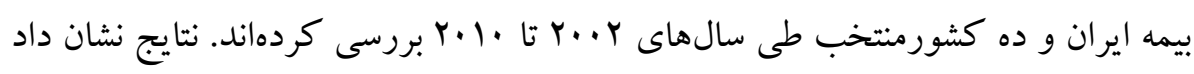
توليد ناخالص داخلى سرانه بهعنوان متغير جانشين توسعه نهادى، داراى اثر منفى و معنى - 
دارى بر تمر كز صنعت بيمه است. همجنين، آزادى اقتصادى بهعنوان ديخر متغير نهادى بر

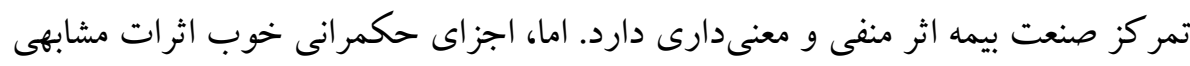

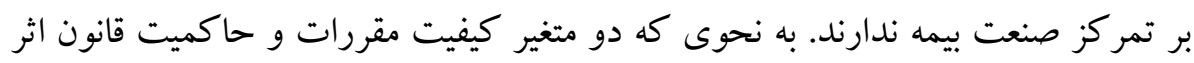
منفى و كنترل فساد و حق اظهارنظر و باسخ كويى اثر مثبت بر تمر كز صنعت بيمه دارند. دو دون

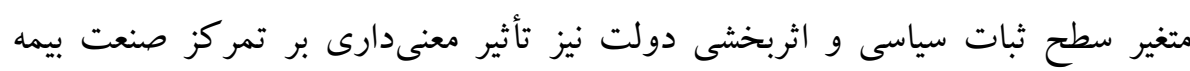
ندارند.

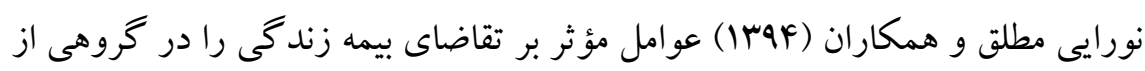

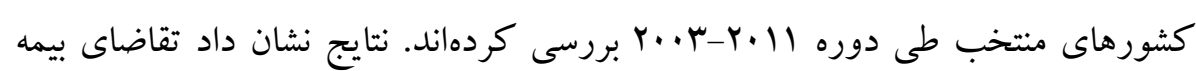

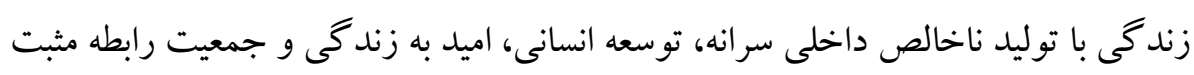
و با تورم و نرخ بهره رابطه منفى دارد.

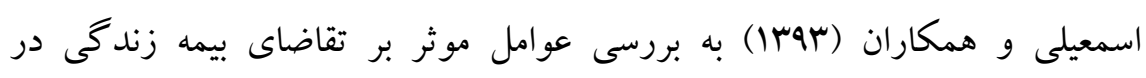

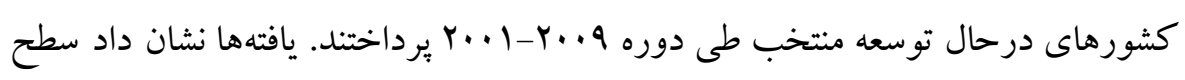
در آمد سرانه، سطح توسعه مالى، حاكميت قانون، سطح تحصيلات و شهرنشينى از جمله

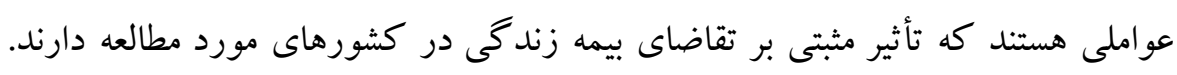

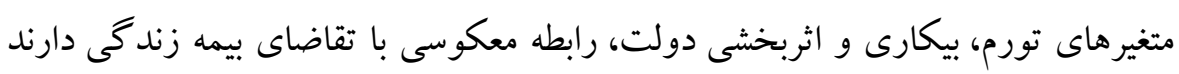

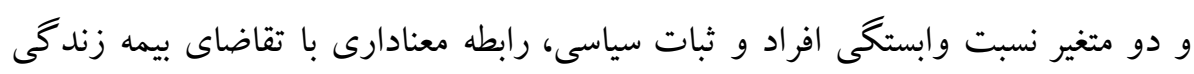
در كشورهاى مورد مطالعه ندارند. نتايج حاصل از مرور مطالعات بيشين نشان مىدهد، بررسى تعيين كنندهاى بيمه،

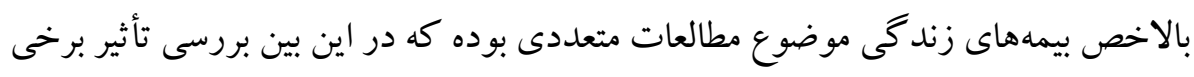
از وجوه رقابت بذيرى ملى نظير سرمايه انسانى و عوامل نهادى نيز بر آن مغفول نمانده

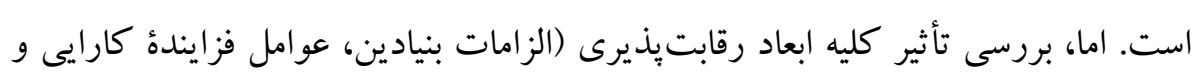
عو امل فزايندهُ توسعه و نو آورى) بر ضريب نفوذ بيمه در مطالعات انجام شده سابقه ندارد.

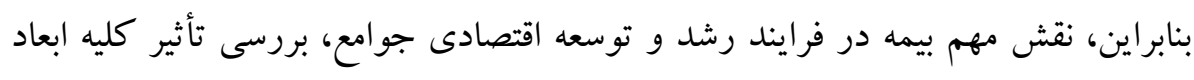

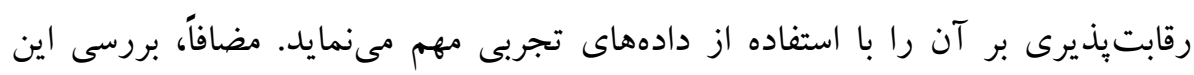


موضوع و ارائه نتايج حاصله در قالب توصيههاى سياستى و ييشنهادات كاربردى در كشورهاى منتخب كارايىمحور كه به استناد شواهد تجربى از ضريب نفوذ بيمه بايينى برخوردارند؛ ضرورت بيشترى دارد و مىتواند به آنها در انجام برنامهريزى و سياست-

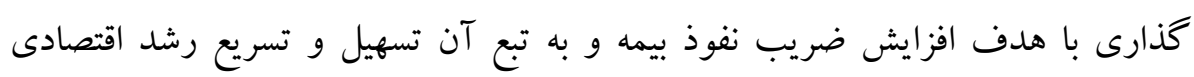
كمكك نمايد.

\section{ع. مدل تحقيق و روش بر آورد}

مدل اقتصادسنجى تحقيق از نوع دادههاى تابلويى 'است. البته، مدل ولود دادههاى تابلويى

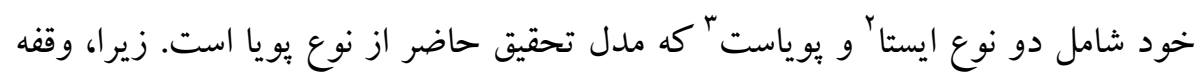
متغيّر وابسته (ضريب نفوذ بيمه) به صورت متغيّر توضيحى در طرف دور راست معادله ظاهر مىشود تا به در كك بهتر محقق از روابط بين متغيرها كمكك نمايد (آرلانو و بوندهُ (1991).

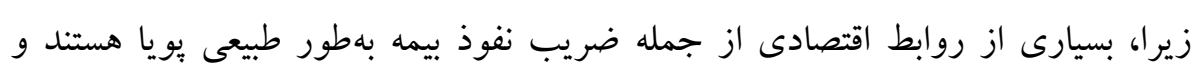

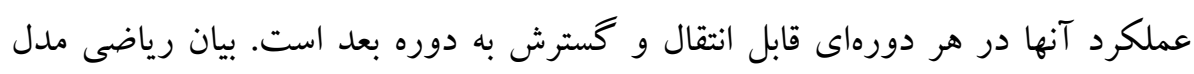

$$
\text { تحقيق بهشرح زير است: }
$$

$\mathrm{LIP}_{\mathrm{it}}=\beta_{0}+\beta_{1} \mathrm{LIP}_{\mathrm{it}-1}+\beta_{2} \mathrm{LGCI}_{\mathrm{it}}+\beta_{3} \mathrm{LPCIG}_{\mathrm{it}}+\beta_{4} \mathrm{LURB}_{\mathrm{it}}+\beta_{5} \mathrm{LDR}_{\mathrm{it}}+\mathrm{U}_{\mathrm{it}}$

مدل بالا به شكل لكاريتمى و براى كشور i در زمان t ${ }^{2}$ بر آورد مى شود. در اين مدل

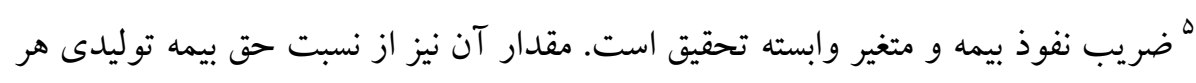
كشور به توليد ناخالص داخلى آن كشور به دست مى آيد. متغير وابسته باوقفه (ضريب نفوذ بيمه با يك دوره تأخير)،

$$
\text { كشورى (عرض از مبدأهاى ويثه هر مقطع) است. }
$$

1. Panel Data

2. Static Panel Data

3. Dynamic Panel Data

4. Arellano \& Bond

5. Insurance Penetration 
شاخص رقابت بذيرى است كه با الهام از مطالعات دارگوس و همكاران

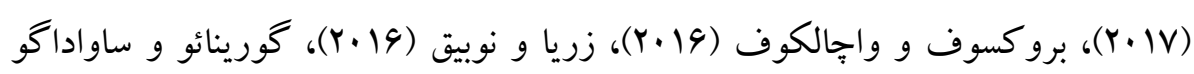

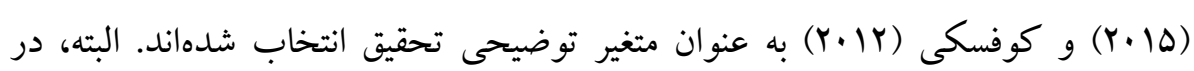

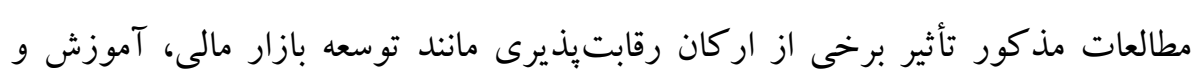
سرمايه انسانى و آمادگى فنى بر بيمه بررسى شده است. اما، تحقيق حاضر تأثير كليه ار كان

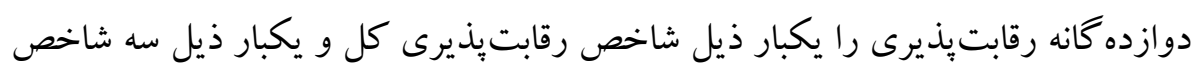

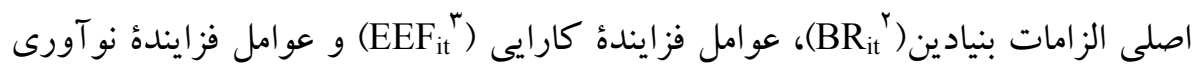
(ISF ${ }^{{ }^{+}{ }^{+}}$

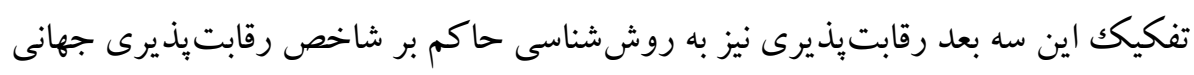

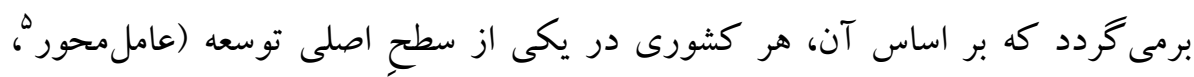

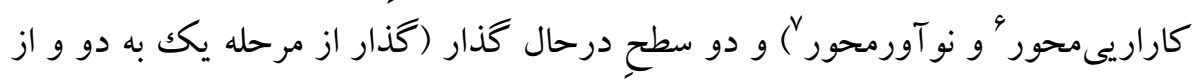
مرحله دو به سه) قرار دارد. كشورهاى واقع در سطح اول توسعه (عاملمحور)، تنها بر

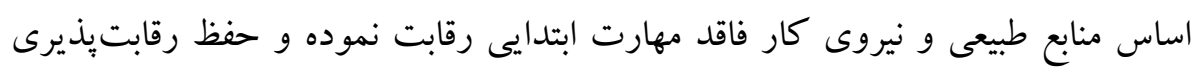
آنها در درجه نخست به عملكرد خوب نهادهاى دولتى و خصوصى (ركن ())، توسعه

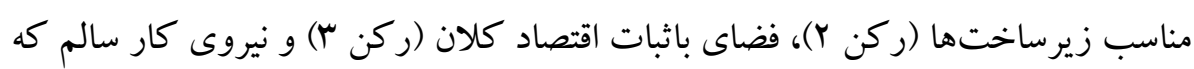

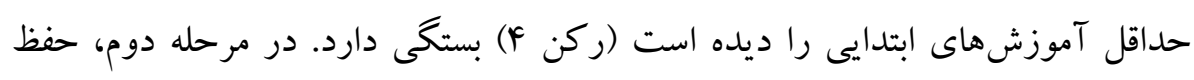
رقابتيذيرى در درجه نخست به سطح آموزش عالى (ركن ه)، كارايى بازار كالا (ركن

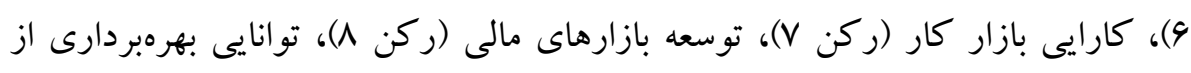

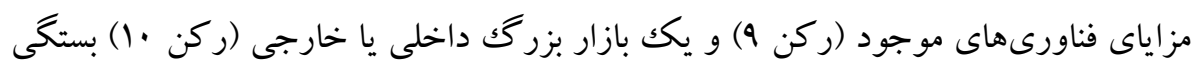

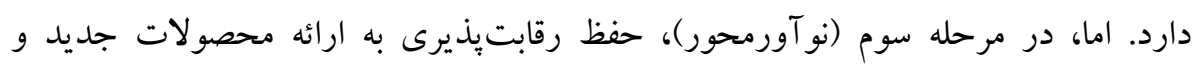

1. The Global Competitiveness Index

2. Basic Requirements

3. Efficiency Enhancers Factors

4. Innovation and Sophistication Factors

5. Factor-Driven Stage

6. Efficiency -Driven Stage

7. Innovation -Driven Stage 


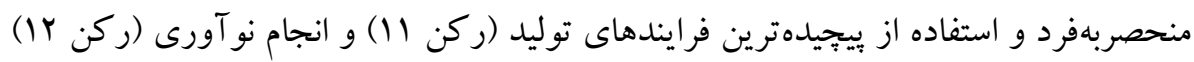

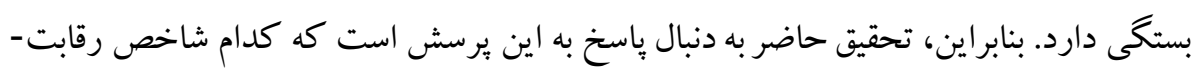
يذيرى بر ضريب نفوذ بيمه در كشورهاى منتخب كارايى محور تأثير بيشترى دارد.

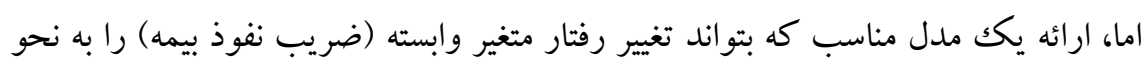
حداكثرى توضيح دهد، مستلزم لحاظ ساير عوامل موثر بر ضريب نفوذ بيمه است كه در اين

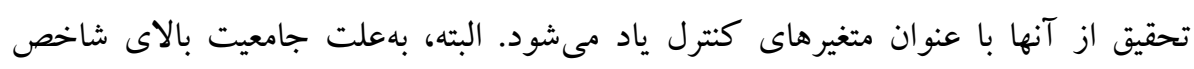

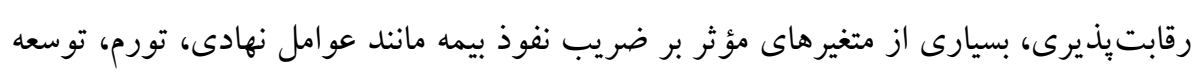

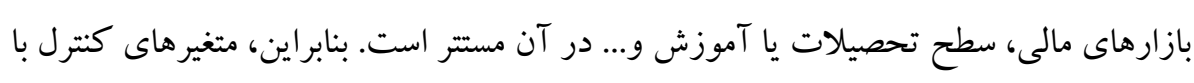

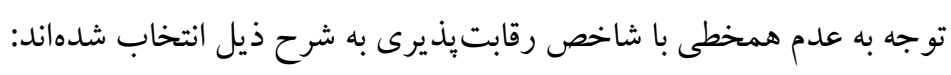

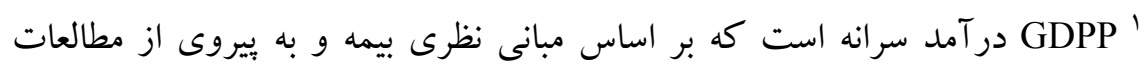

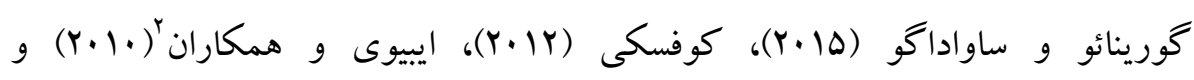
سبيردوست و ابراهيم نسب (Y (1) انتخاب شده و انتظار مىرود بر ضريب نفوذ بيمه تأثير

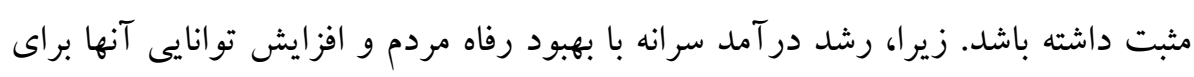
خريد بيمهنامه همر اه است. درجه شهرنشينى است كه به صورت درصد افراد شهرنشين به كل جمعيت تعريف شده است. اين متغير بر اساس مبانى نظرى بيمه و به بيروى از مطالعات راگوس و و همكاران

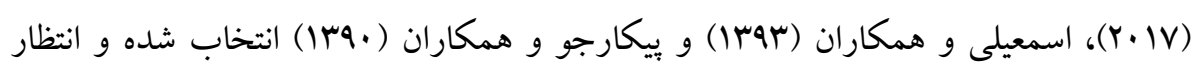

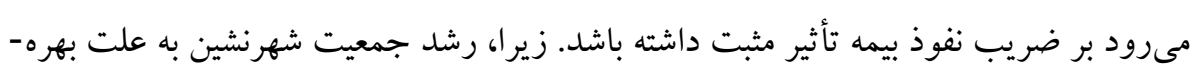

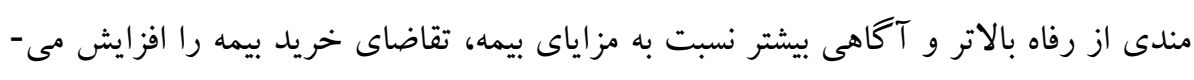

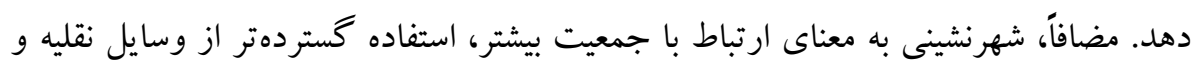
تماس بيشتر با ماشين آلات در محيط كسبو كار است كه با افزايش نااطمينانى و احتمال بروز

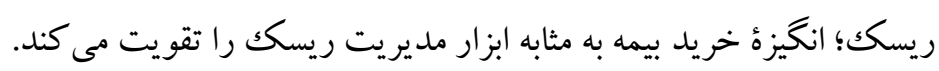


بار تكفل است و بر اساس مبانى نظرى بيمه و به بيروى از مطالعات زريا و نوبيق

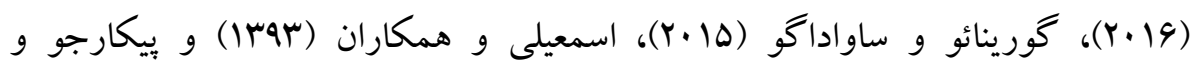

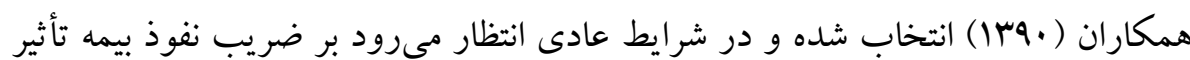
مثبت داشته باشد. زيرا، با افزايش تعداد افراد تحت تكفل، سريرست خانوار ضرورت بيشترى به خريد بيمه احساس مى كند تا در صورت بى سريرستى و ويشامدهاى مخرب، آتيه

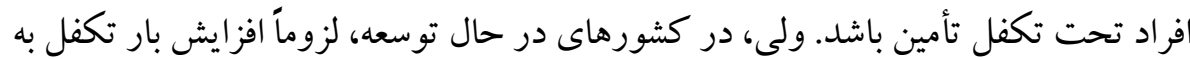
رشد تقاضاى بيمه و افزايش ضريب نفوذ بيمه منجر نمىشود. زيرا، در آمد يائين سريرست خانوار تكافوى برداخت حق بيمه براى كليه افراد تحت تكفل را نمىدهد. 0. دادهها و نتايج تجربى

در اين تحقيق، ايستايى متغيرها با انجام آزمونهاى ديكى فولر تعميميافته بو هادرى بررسى و نتايج در جدول الارائه شده است.

جدول ا: نتايج آزمون ايستايى متغيرها

\begin{tabular}{|c|c|c|c|c|c|}
\hline \multirow[b]{2}{*}{ نتيجه } & \multicolumn{2}{|c|}{ ADF } & \multicolumn{2}{|c|}{ Hadri Stationary test } & \multirow[b]{2}{*}{ متغير } \\
\hline & يذيرش صفر احتمال & مقدار بحر انى & يذيرش صفر & مقدار بحرانى & \\
\hline $\mathrm{I}(0)$ & $\cdot / \cdot$ & $-Y / \Lambda I$ & $\cdot / \cdot$ & $\Delta / \mu_{F}$ & IP \\
\hline $\mathrm{I}(0)$ & $\cdot / \cdot$ & $-Y / \cdot V$ &.$/ \cdot$ & $\mathrm{V} / \mathrm{IV}$ & GCI \\
\hline $\mathrm{I}(0)$ & $\cdot / \cdot$ & $-Y / M$ &.$/ \cdot$ & $\mu / \cdot \Delta$ & $\mathrm{BR}$ \\
\hline $\mathrm{I}(0)$ &.$/ \cdot$ & $-r / 99$ & $\%$ & & EEF \\
\hline $\mathrm{I}(0)$ &.$/ \cdot$ & $-Y / Y I$ & $\%$ & V/FA & ISF \\
\hline $\mathrm{I}(0)$ &.$/ \cdot$ & $r / \Delta r$ & $\%$ & G/VA & GDPP \\
\hline $\mathrm{I}(0)$ & $\cdot / \cdot$ & $-r / M r$ & $\%$ & $\Delta / V^{\mu}$ & UP \\
\hline $\mathrm{I}(0)$ & $\cdot / \cdot$ & $-r / \Lambda F$ & $\%$ & $F / M Y$ & DR \\
\hline
\end{tabular}


فرايند بررسى ايستايى در روشهاى هادرى و ديكى فولر تعميميافته به اين صورت

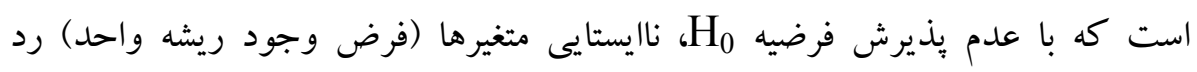

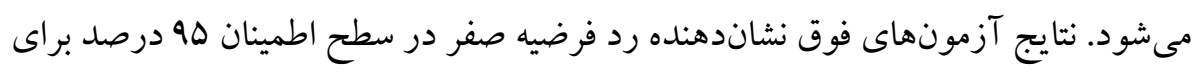
كليه متغيرهاى به كار رفته در مدل است. بنابراين، ايستايى متغيرها تأييد و احتمال كاذب ردئ بودن ر خرسيون بر آوردى منتفى شد.

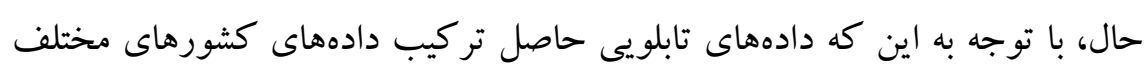

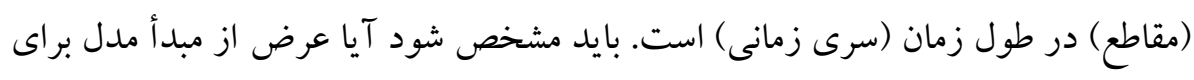
مقاطع مختلف يكسان است يا خير؟ در صورتى كه هيجِكدام از اثرات مقطعى يا زمانى

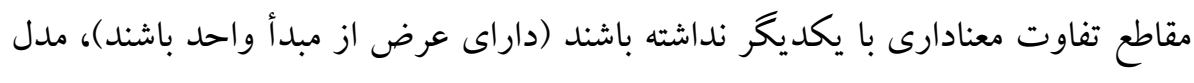

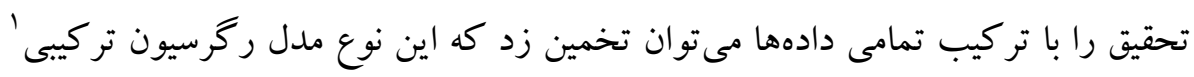

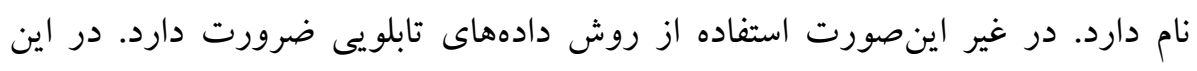

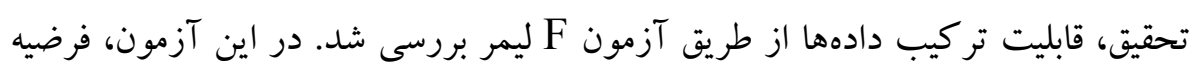
قابليت تخمين مدل به صورت دادههاى تلفيقى 'و فرضيه H $\mathrm{H}_{0}$

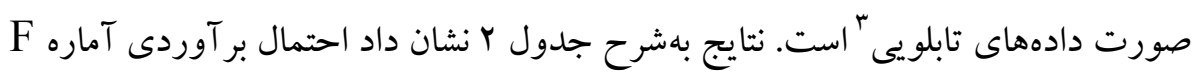
در هر دو حالت كمتر از هـ/• است. بنابراين، قابليت تخمين مدل بهصورت دابت دادههاى

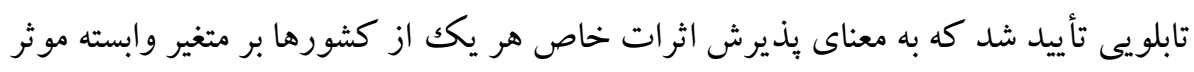

\begin{tabular}{|c|c|c|c|}
\hline نتيجه & ارزش احتمال & Tاره F F F & حالت \\
\hline دادههاى تابلويى & $\cdot / \cdot$ & $r F / 99$ & اول \\
\hline دادههاى تابلويى & $\cdot / \cdot$ & $r M / T F$ & دوم \\
\hline
\end{tabular}


همجنين، از آزمون سار كان براى بررسى اعتبار متغيرهاى ابزارى تعريف شده در مدل

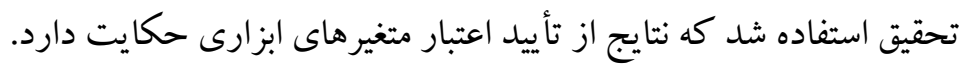

جدول Гّ: نتايج آزمون بررسى اعتبار متغيرهاى ابزارى

\begin{tabular}{|c|c|c|c|}
\hline نتيجه & ارزش احتمال & آماره آزمون والد ( & حالت \\
\hline تأيد اعتبار متغيرهاى ابزارى & $\cdot|q|$ & I/AF & اول \\
\hline تأييد اعتبار متغيرهاى ابزارى &.$/ A F$ & $1 / 19$ & دوم \\
\hline
\end{tabular}

بس از انجام آزمون اعتبار متغيرهاى ابزارى، براى تشخيص مرتبه خودهمبستكى بين

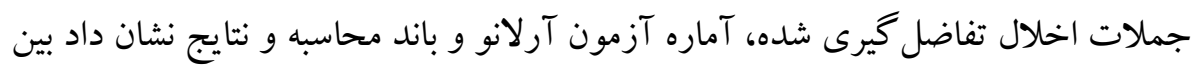
جملات اخلال تفاضل گيرى شده خودهمبستكى مرتبه اول و دوم وجود ندارد.

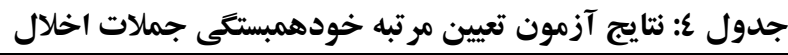

\begin{tabular}{|c|c|c|c|c|}
\hline نتيجه & ارزش احتمال & آماره آزمونZ & مرتبه خودهمبستخى & حالت \\
\hline عدم وجود خودهمبستكى & $\cdot / \mathrm{VV}$ & $\cdot / r \wedge$ & 1 & \multirow{2}{*}{ اول } \\
\hline عدم وجود خودهمبستخى & $\cdot / 9 V$ & $\cdot / \cdot 1$ & $r$ & \\
\hline عدم وجود خودهمبستخى & $\cdot / V^{F}$ & $\cdot / Y^{4}$ & 1 & \multirow{2}{*}{ دوم } \\
\hline عدم وجود خودهمبستكى & $\cdot / 90$ &.$/ \cdot 1$ & r & \\
\hline
\end{tabular}

منبع: يافته هاى بثووهش

در نهايت، نظر به اين كه در مدل دادههاى تابلويى يويا به واسطه اضافه شدن متغير

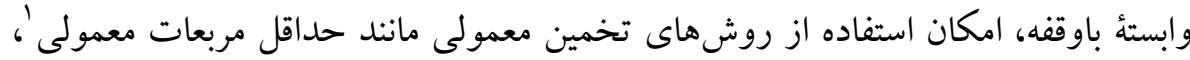

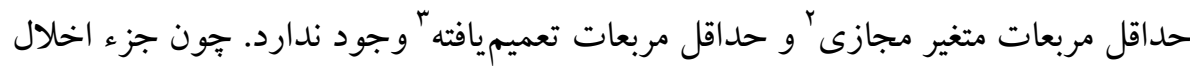

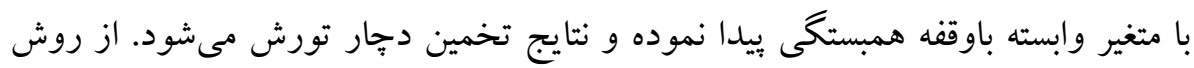


كشتاورهاى تعميميافته' براى برآورد مدل تحقيق استفاده شد كه توسط آرلانو و باند

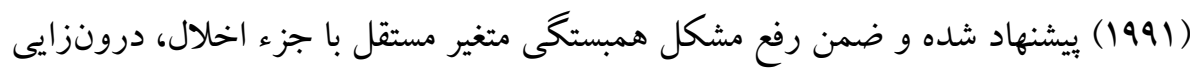

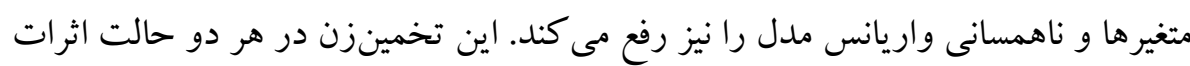

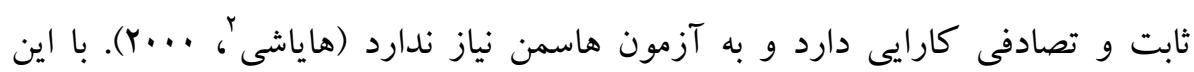
توضيح، نتايج تخمين مدل در جدول بارائه شده است.

جدول 0: نتايج تخمين مدل به روش تشتاورهاى تعميميافته

\begin{tabular}{|c|c|c|c|c|c|}
\hline \multicolumn{6}{|c|}{ متغير وابسته: ضريب نفوذ بيمه } \\
\hline \multicolumn{2}{|c|}{ حالت دوم } & \multicolumn{2}{|c|}{ حالت اول } & \multicolumn{2}{|c|}{ متغير هاى توضيحى } \\
\hline 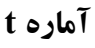 & ضريب & t to to & 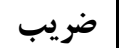 & 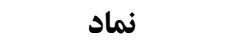 & 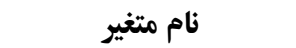 \\
\hline $9 / 9 \mathrm{~V}$ & $\cdot / \Gamma 4^{*}$ & q/ro & $\cdot / \mu r^{*}$ & $\operatorname{LIP}(-1)$ & ضريب نفوذ بيمه باوقفه \\
\hline T/M & $\cdot / \Upsilon \Lambda^{* * * * *}$ & - & - & LGCI & رقابت يذيرى كل \\
\hline- & - & r/ar &.$/ 1 V^{* * * *}$ & LBR & الزامات بنيادين \\
\hline- & - & $F / \Lambda$ & $\cdot / \Upsilon^{* * * * *}$ & LEEF & عوامل فزاينده كارايى \\
\hline- & - & $F / I r$ & $\cdot / \mu \Lambda^{* * * *}$ & LISF & عوامل فزاينده نو آورى \\
\hline $9 / 44$ &.$/ 1 V^{*}$ & $9 / .9$ &.$/ 1 f^{*}$ & GDPP & در آمد سرانه \\
\hline$r / 9 \Lambda$ & $\cdot / 10^{* * * *}$ & $4 / .9$ & $\cdot / 19^{* * * *}$ & LURB & نرخ شهرنشينى \\
\hline$-Y / \cdot \wedge$ & $-\cdot / \cdot Y^{* * * * * *}$ & $-r / \cdot V$ & $-\cdot / \cdot 1^{* * * * * *}$ & LDR & بار تكفل \\
\hline \multicolumn{2}{|c|}{$r$. } & \multicolumn{2}{|c|}{ r. } & Number of groups & تعداد كشورها \\
\hline \multicolumn{2}{|c|}{11} & \multicolumn{2}{|c|}{11} & Obs per group & تعداد مشاهده براى هر كشور \\
\hline \multicolumn{2}{|c|}{ rr. } & \multicolumn{2}{|c|}{ rr. } & Number of obs & تعداد كل مشاهدات \\
\hline
\end{tabular}

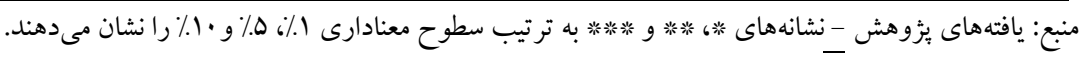


7. نتيجه تيرى

در اين تحقيق، تأثير شاخص رقابتيذيرى كل و شاخصهاى اصلى آن شامل الزامات

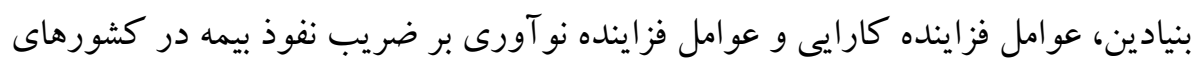

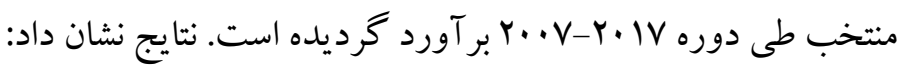
تأثير شاخص رقابتيذيرى كل بر ضريب نفوذ بيمه در كشورهاى منتخب مثبت و

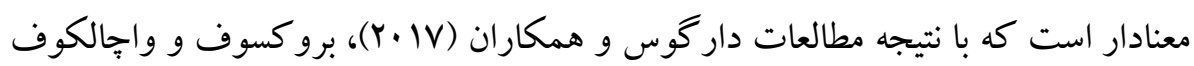

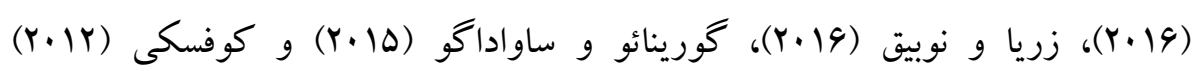
همخو انى دارد. بهور مشخص، تأثير الزامات بنيادين رقابتيذيرى بر ضريب نفوذ بيمه در كشورهاى

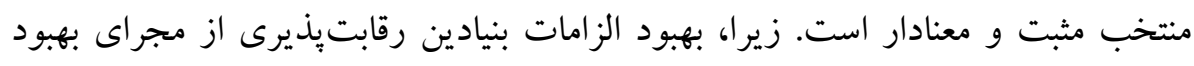

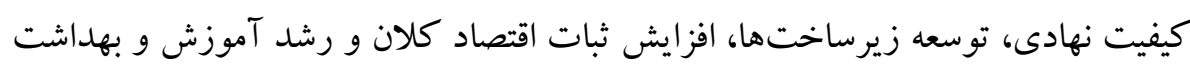
سبب بهبود فضاى كسبو كار، توسعه فعاليتهاى اقتصادى، بسط عرضه و تقاضاى خدمات بيمهاى و افزايش ضريب نفوذ بيمه شده است. تأثير عوامل فزاينده كارايى بر ضريب نفوذ بئ بيمه در كشورهاي منده منتخب مثبت و معنادار

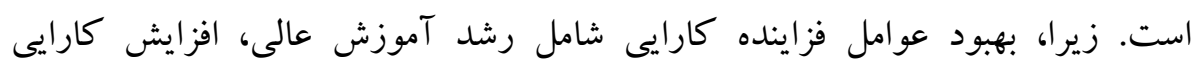

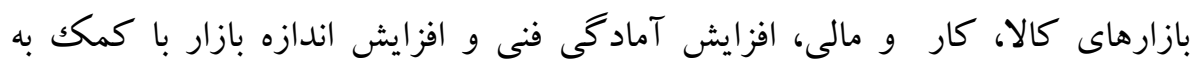

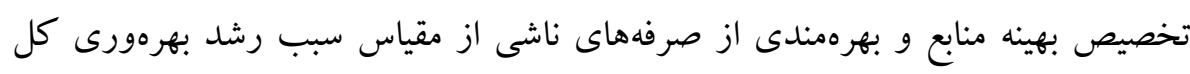

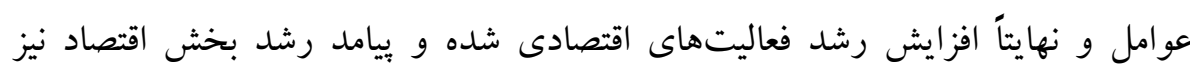
افزايش تقاضاى خدمات بيمهاى و رشد عرضه آن جهت براسخكويى به اين تقاضاها بوده كه در نهايت به افزايش ضريب نفوذ بيمه در جامعه انجاميده است.

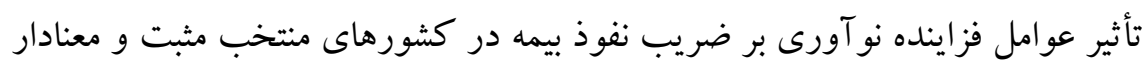

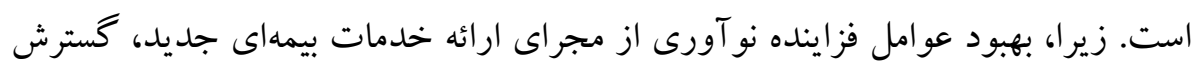

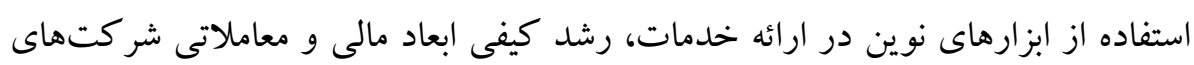


بيمه و افزايش رقابت پيذيرى آنها در بازارهاى داخلى و خارجى به رشد حق بيمه توليدى و

$$
\text { افزايش ضريب نفوذ بيمه كمكك نموده است. }
$$

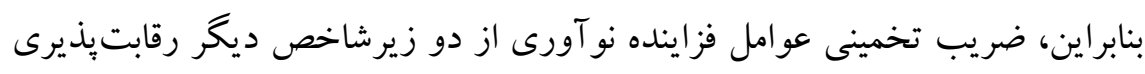

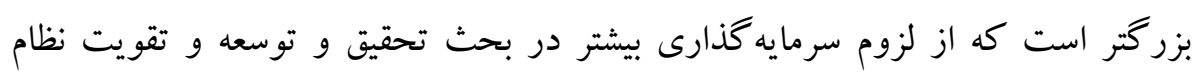
نو آورى ملى جهت افزايش ضريب نفوذ بيمه حكايت دارد.

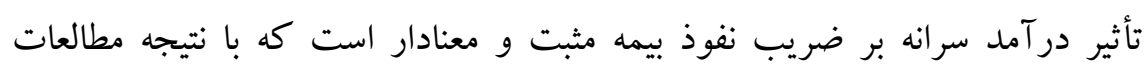

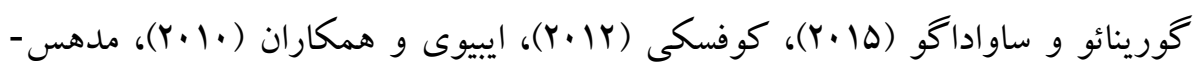

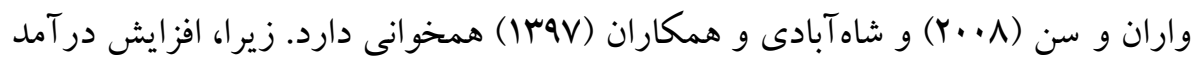

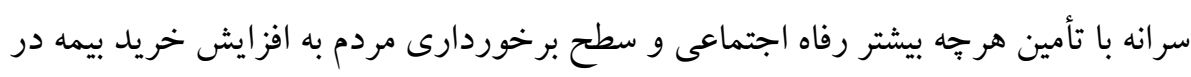
جامعه منجر شده است. تأثير نرخ شهرنشينى بر ضريب نفوذ بيمه در كشورهاى منتخب مثبت و معنادار است كه

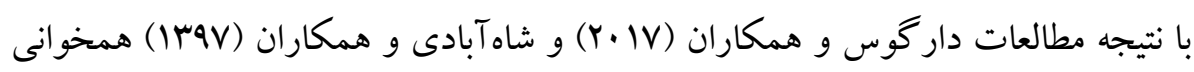

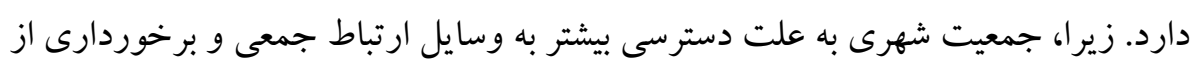

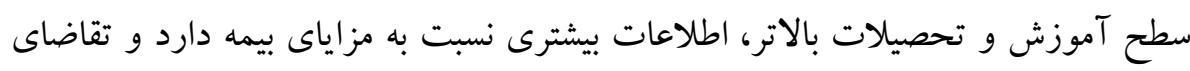
بيشترى براى بيمه داشته است.

تأثير بار تكفل بر ضريب نفوذ بيمه در كشورهاى منتخب منفى و معنادار است كه با بائه

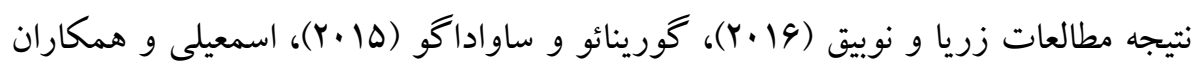

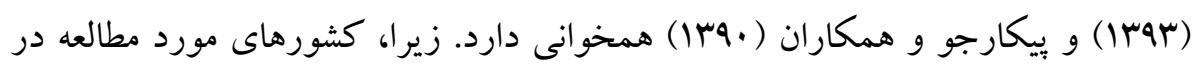

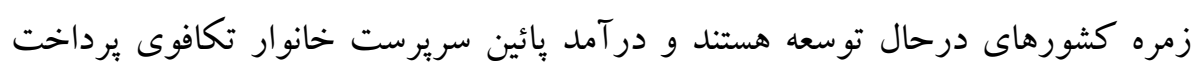

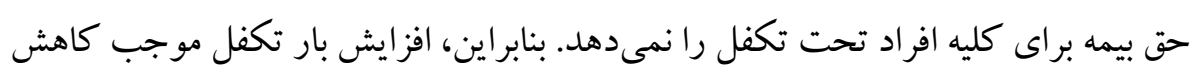
تقاضاى خريد بيمه شده است. تأثير متغير وابسته باوقفه بر ضريب نفوذ بيمه در كشورهاى منتخب مثبت و معنادار است

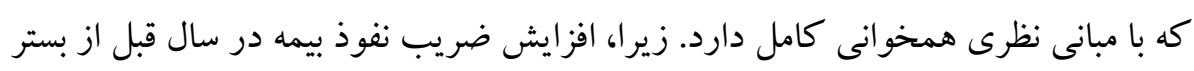


مناسب براى اين كار حكايت دارد كه با انتقال اين شرايط به دوره بعد موجبات افزايش

$$
\text { مجدد ضريب نفوذ بيمه فراهم شده است. }
$$

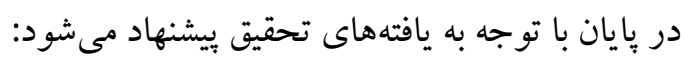

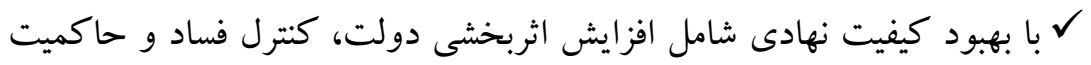

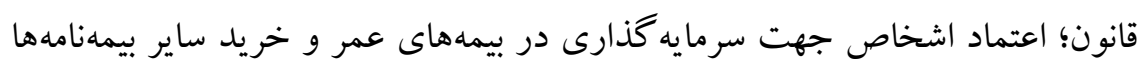

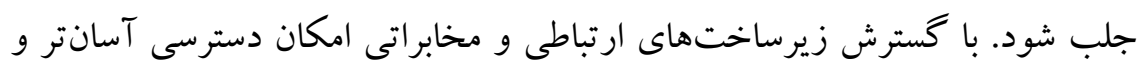
كم هزينهتر آحاد جامعه به خدمات بيمهاى فراهم شود. با بهبود محيط اقتصاد كلان از

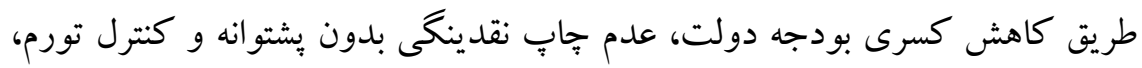

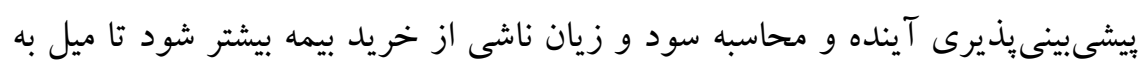

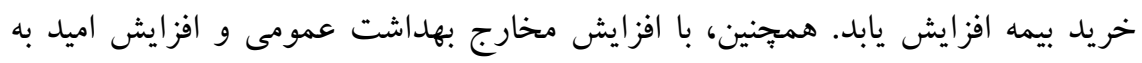

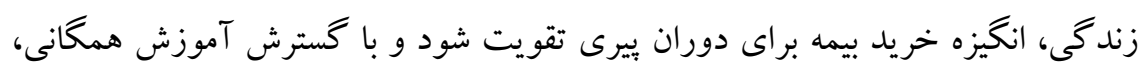

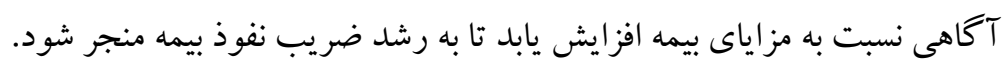

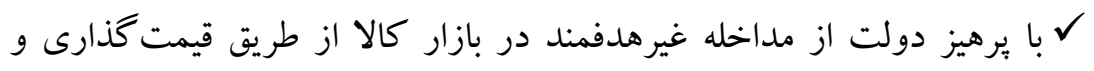

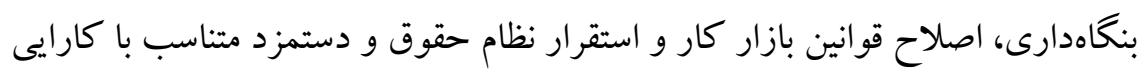
نيروى كار، واگذارى مالكيت بانككهاى دولتى و عدم سركوب مالى بالى، توسعه نظام آموزش عالى و آموزش حين خدمت متناسب با نياز بازار (سمت تقاضا) در جهت بهبود عوامل فزاينده كارايى اقتصاد اقدام شود تا با ايجاد رونق در كسبو بورئ كارها، زمينه مناسب براى رشد عرضه و تقاضاى خدمات بيمهاى فر اهم شود. لا با توسعه فعاليتهاى تحقيق و توسعه، حمايت قانونى از مالكيت معنوى، تأمين

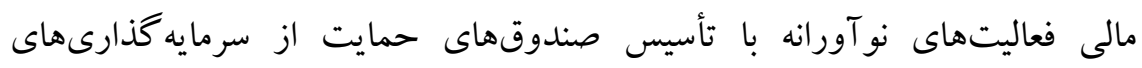

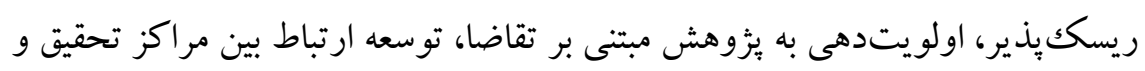

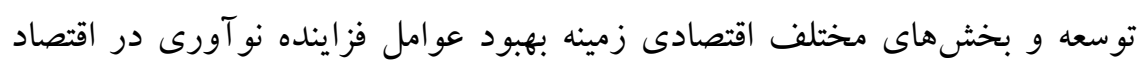
بهطور عام و صنعت بيمه بهطور خاص فراهم شود تا به بسط عرضه و تقاضاى خدمات بيمهاى و رشد ضريب نفوذ بيمه منجر شود. 
- Arellano, M. \& Bond, S. (1991). Some tests of specification for panel data: Monte Carlo evidence and an application to employment equations. Review of Economic Studies, 58(2): 277-297.

- Asadi Gharagozlou, S., Daghighi Asl, A., Mahdavi., G. \& Damankeshideh, M. (2019). Impact of globalization on insurance penetration of comparative comparison of perspective countries of Iran and developed countries. 26th National Conference on Insurance and Development, date 2019-12-4 by Insurance Research Institute, Tehran. (in persian).

- Berg, H. V. D. \& Schmidt, J. R. (1994). Foreign trade and economic growth: Time series evidence from Latin America. The Journal of International Trade and Economic Development: An International and Comparative Review, 3(3): 249-268.

- Brokesova, Z. \& Vachalkova, I. (2016). Macroeconomic environment and insurance industry devel- opment: The case of Visegrad group countries. Central European Review of Economic, 19(2): 63-72.

- Dragos, S. L., Mare, C., Dragota, I. M., Dragos, C. M. \& Muresan. G. M. (2017). The nexus between the demand for life insurance and institutional factors in Europe: New evidence from a panel data approach. Economic Research-Ekonomska Istraživanja, 30(1): 1477-1496.

- Ehiogu, C. P., Onyekachi, E. R. \& Sunday, N. C. (2018). Effect of inflation rate on insurance penetration of Nigerian insurance industry. International Research Journal of Finance and Economics, 170(1): 6676.

- Esmaili, F., Mirzaei, H. \& Asadzadeh, A. (2014). Factors affecting life insurance demand in developing selected countries. Iranian Journal of Insurance Reserch, 29(4): 61-83. (in persian).

- Ghasemi, A. R. \& Farzaneh, S. (2015). The impact of institutional factors and macroeconomic variables on Iranian insurance industry structure and selected countries. Journal of Insurance Research, 1(1): 35-54. (in persian).

- Guerineau, S. \& Sawadogo, R. (2015). On the determinants of life insurance development in Sub-Saharan Africa: The role of the institutions quality in the effect of economic development. Working Paper 201519. 
- Gupta, R., Lahiani, A., Lee, C. C. \& Lee, C. C. (2019). Asymmetric dynamics of insurance premium: The impacts of output and economic policy uncertainty. Empirical Economics, 57(6): 1959-1978.

- Hasanzadeh, A. \& Kazemnejad, M. (2011). The role of information technology in the insurance industry business. 18th National and 4th International Conference on Insurance and Development In date 2011-1129 by in Tehran was held.

- Jahangard, E. (2011). Insurance and economic growth : The case of Iran's economy. Journal of Economic Research and Policies, 19(59) :53-80. (in persian).

- Nouraei Motlagh, S., Lotfi, F., Mohajerzadeh, Z., Abolghasem Gorji, H. \& Omranikhoo, H. (2016). A study of determinants on demand for life insurance in selected countries. Journal of Health Administration, 19(63) :9-20. (in persian).

- Onafalujo, A. K. (2019). Underwriting performance shocks in the nonlife Nigerian insurance industry and macroeconomic risks: A vector auto regressive approach. Economics and Organization, 16(2): 129-144.

- Peleckiene, V., Peleckis, K., Dudzeviciute, G. \& Kestutis K. P. (2019). The relationship between insurance and economic growth: evidence from the European Union countries. Economic Research-Ekonomska Istraživanja, 32(1): 1138-1151

- Sadegh, N., Sajadi, S. A. \& Agili, S. V. (2013). The role of establishing e-government on efficiency of insurance companies (case study, Iran insurance company). Journal of Urban Management Studies, 5(16): 97107. (in persian).

- Sepehrdoust, H. \& Ebrahimnasab, S. (2013). Good governance and life insurance demand; Economic challenges in developing countries. Quarterly Journal of The Macro and Strategic Policies, 1(3): 39-54. (in persian).

- Sepehrdoust, H. \& Ebrahimnasab, S. (2016). Impact of administrativefinancial-corruption control on financial development of life insurance market. Iranian Journal of Insurance Reserch, 31(1): 81-101. (in persian).

- Shahabadi, A., Ahmadi, M. \& Moradi A. (2018). The interaction of financial development and economic freedom on insurance penetration 
unsuccessful countries in the development of the insurance industry. Journal of Economic Modeling Research, 8(31): 41-68. (in persian).

- Shahabadi, A. \& Sadeghi, H. (2012). Competitiveness assessment of OPEC member: with an emphasis on innovation-driven componets. Journal of roshde-fanavari, 8(29): 3-15. (in persian).

- Shahikitash, M. N. (2013). A study of concept of competition in economics and it size in Iranian economy. Journal of Business Reviews, 11 (60): 1-16. (in persian).

- Shirkavand, S. (2012). Monetary and financial organizations. Kavir Publications, First Edition. (in persian).

- Soo, H. H. (1996). Life insurance and economic growth: theoretical and empirical investigation. University of Nebraska, Lincoln.

- Van Wyk, J. (2010). Double diamonds, real diamonds: Botswana's national competitiveness. Academy of Marketing Studies Journal, 14(2): 55-76.

- Vares, S. H., Mohammadi, S. \& Parvandi, Y. (2012). On economic prosperity: Providing a model for improving national competetiveness of Iran. Iranian journal of management sciences, 7(26): 25-48. (in persian).

- Yadollahzadeh Tabari, N., A. \& Shahrokhi Sahneh, M. (2015). A study of relationship between risk avoidance and demand for life insurance. Second National Conference on Applied Economics and Management, date 2015-07-20 by in Babolsar was held. (in persian).

- Yu, P. \& Guo, P. (2014). An analysis of the synergy degree of insurance innovation and financial development in China. International Conference on Logistics Engineering, Management and Computer Science (LEMCS 2014) will be held from May 24 to 26, 2014, in Shenyang, China.

- http://data.worldbank.org/data-catalog/world-development-indicators.

- http://www.swissre.com/sigma. 


\title{
The Effect of National Competitiveness on Insurance Penetration in Selected Countries
}

\author{
Abolfazl Shahabadi ${ }^{1}$, Hossein Raghfar $^{2}$, Neda Solgi ${ }^{3}$, Ali Moradi ${ }^{4}$
}

Received: 2019/06/14 Accepted: 2020/03/18

\begin{abstract}
Insurance as a central risk-taking institution as well as one of the investment institutions increases economic participation, investment development and stimulating economic growth. Therefore, identification of the effective factors on the insurance penetration in developing countries seems necessary. In this regard, the present study attempted to investigate the impact of national competitiveness on insurance penetration coefficient in 20 developing countries during the period 2007-2017. The research model was estimated using panel data and generalized moment's method in two case. In the first case, the sub-indicators of national competitiveness including basic requirements, efficiency enhancer's factors and innovation and sophistication factors were used as key variables in the research, and in the second case, the overall competitiveness index is used as a key variable in the research model. The results showed that the effect of overall competitiveness index and its sub-indicators on insurance penetration was positive and significant. Also, the effect of control variables, including per capita income and urbanization rate on insurance penetration is positive and significant, and the effect of dependency ratio on insurance penetration is negative and significant.
\end{abstract}

Keywords: Insurance Penetration, Competitiveness, Panel Data. JEL Classification: G22, O43, O33. 